\title{
Wpływ niepewności wybranych parametrów geologicznych i błędów pomiarowych na wyznaczanie wydobywalnych zasobów gazu w krajowych formacjach łupkowych metodą krzywych spadku wydajności
}

\begin{abstract}
W artykule przedstawiono analizę dokładności wyznaczania wydobywalnych zasobów krajowych formacji łupkowych przy pomocy krzywych spadku wydajności. Obejmowała ona wybór krzywej spadku, długość analizowanego okresu eksploatacji oraz obecność błędów pomiarowych w danych eksploatacyjnych. W pracy przetestowano cztery typy modeli krzywych spadku wydajności: klasyczny model krzywej hiperbolicznej, model krzywej ,wykładniczej rozciągniętej” (stretched exponential), model krzywej Duonga i model krzywej logistycznej (logistc growth). Procedurę dopasowania krzywych spadku wydajności do danych eksploatacyjnych przeprowadzono dla czterech różnych okresów uwzględniających spadkową fazę wydajności wydobycia i odpowiadających efektywnej długości 1 roku, 2, 3 i 4 lat eksploatacji. Dane eksploatacyjne wygenerowano, wykorzystując symulacyjne modele złożowe formacji o parametrach geologicznych i charakterystykach udostępnień typowych dla dotychczas nawierconych i testowanych krajowych formacji łupkowych. Wpływ błędów pomiarowych na wyniki procedury uwzględniono poprzez zaburzenie danych eksploatacyjnych błędem o rozkładzie normalnym z różnym odchyleniem standardowym (o wartości: 1\%,3\%, $5 \%$ i 10\% wartości danych). Zastosowana procedura dopasowania krzywych spadku wydajności, o charakterze regresji nieliniowej, pozwoliła wyznaczyć jednoznacznie komplet parametrów opisujących krzywe spadku, a w konsekwencji określić sumaryczne wydobycie traktowane jako zasoby wydobywalne analizowanej strefy drenażu. Porównanie tej wielkości z analogicznymi wynikami symulacji modelu złożowego stanowi miarę błędu szacowania zasobów wydobywalnych metodą krzywych spadku wydajności. Sformułowano następujące wnioski odnośnie dokładności szacowania wydobywalnych zasobów formacji łupkowych przy pomocy analizowanej metody na podstawie dużej liczby alternatywnych wariantów modeli formacji. Statystycznie najdokładniejsze szacowanie zasobów, w porównaniu z innymi analizowanymi modelami, zapewnia krzywa Duonga. Bardziej szczegółowa analiza wpływu wartości poszczególnych parametrów geologicznych formacji na dokładność szacowania zasobów pokazuje, że błąd szacowania zasobów jest tym większy, im bardziej przepływy w eksploatowanej formacji odbiegają od przepływów stacjonarnych (semistacjonarnych). Względny błąd wyznaczenia zasobów na poziomie $10 \%$ wymaga minimum 3-letniego okresu analizy. Dla krótszego czasu błąd ten jest co najmniej rzędu 20\% - w przypadku 2 lat i 50\% dla okresu rocznego. Błędy pomiarowe w danych eksploatacyjnych zwiększają niepewność szacowania zasobów wydobywalnych, gdy pozostałe czynniki pozwalają na względnie dokładne wyznaczenie zasobów $(\leq 10 \%)$ oraz praktycznie nie wpływają na błąd ich szacowania w przypadkach dużych rozbieżności (>20\%) spowodowanych tymi czynnikami.
\end{abstract}

Słowa kluczowe: formacje łupkowe, krzywe spadku wydajności, symulacyjne modele złożowe, zasoby wydobywalne.

\section{Influence of selected geological parameters uncertainty and production data errors upon} the estimation of recoverable resources of domestic shale gas formations using ratedecline analysis

The paper presents investigations of assessment accuracy for recoverable resources of Polish shale gas formations using rate-decline analysis. The investigations include selection of different decline curves, production data period available for analysis and production data errors. Four rate-decline models were tested: hyperbolic model, stretched exponential model, Duong's model and logistic growth model. The analysis was performed for four different periods 
of production taking into account various phases of rate behavior and corresponding to effective time of $1,2,3$, and 4 years. Production data were generated with the simulations of reservoir models constructed for shale formations of geological and completion characteristics typical for formations drilled and tested in Poland. The influence of production data errors upon the results of the investigated method was examined by the deformation of the production data with errors of standard distribution and various standard deviations ( $1 \%, 3 \%, 5 \%$ and $10 \%$ of original data). The procedure of rate-decline curve fitting to the production data, employed nonlinear regression technique and resulted in the precise determination of decline curve parameters, and consequently, in the estimation of total production, that under the appropriate abandonment conditions becomes the value of recoverable resources. This value, in comparison to the analogous results of reservoir simulations, defines the uncertainty of recoverable resources estimated by the rate-decline analysis. Based on a large set of alternative models of the shale formations, the following conclusions were drawn. On average, the most precise estimation of the recoverable resources is provided by the Duong model. Detailed analysis of the influence of various geological parameters upon the estimation results, shows that the larger deviation of reservoir flow from that of conventional reservoirs, implies the larger estimation error. To obtain an error in the order of $10 \%$ requires at least a 3-year's period of production data analysis. For shorter periods the error is typically larger than 20\% and 50\% for 2-year's and 1-year's period, respectively. Production data errors cause the resource estimation uncertainty to increase if the other factors provide relatively precise estimation $(\leq 10 \%)$ and practically do not affect the uncertainty if those factors result in small estimation precision ( $>20 \%)$.

Key words: shale formations, rate-decline curves, reservoir simulation models, recoverable reserves.

\section{Wstęp}

Publikacja stanowi kolejny etap opracowań realizowanych w ramach projektu Blue Gas pt. Dobór optymalnej metodyki szacowania zasobów oraz ryzyk poszukiwawczych (geologicznych i komercyjnych) złóż niekonwencjonalnych typu ,, shale gas”, ,, shale oil” oraz ,tight gas” w Polsce oraz opracowanie metodyki dokumentowania złóż niekonwencjonalnych, zadanie WP1.7 pt. Opracowanie metod i narzędzi probabilistycznej oceny zasobów gazu w złożach niekonwencjonalnych dla dynamicznych metod ich wyznaczania - mających na celu wybór efektywnej metodyki oraz jej wykorzystanie w postaci realistycznego narzędzia, pozwalającego dokonywać szacowania zasobów gazu w złożach niekonwencjonalnych w oparciu o dane eksploatacyjne. Zadanie to dotyczy zasobów wydobywalnych w odróżnieniu od zasobów geologicznych, dla wyznaczenia których wystarczy użyć statycznych danych geologicznych analizowanej formacji.

Chociaż zasoby wydobywalne są powiązane z zasobami geologicznymi efektywnym współczynnikiem sczerpania, to w odróżnieniu od złóż konwencjonalnych, gdzie można go szacować na podstawie wcześniejszych doświadczeń z określonym typem złóż, w przypadku złóż niekonwencjonalnych współczynnik ten wymaga niezależnego określenia. Przyczyną tego jest brak wcześniejszych danych pozwalających na jego wyznaczenie w specyficznych warunkach formacji krajowych, jak również ich odmienność od formacji eksploatowanych w innych regionach (np. formacji łupkowych na terenie USA).

Spośród trzech standardowych metod wyznaczania zasobów wydobywalnych (symulacyjne modele złożowe, krzywe spadku wydajności, bilans materiałowy) do realizacji postawionego wyżej zadania zastosowano metodę krzywych spadku wydajności, która charakteryzuje się względną prostotą $\mathrm{w}$ porównaniu z zaawansowanymi metodami symulacyjnymi modeli złożowych oraz zasadniczą stosowalnością w odróżnieniu od metod bilansu materiałowego wymagających spełnienia warunku stacjonarności (lub szerzej semistacjonarności) przepływów płynów złożowych, nieosiągalnego w złożach niekonwencjonalnych.

W pracy skoncentrowano się na problematyce dokładności wyznaczania zasobów wydobywalnych formacji łupkowych wybraną metodą. Przeprowadzono analizę tej dokładności ze względu na wybór typu krzywej spadku, długość analizowanego okresu oraz obecność błędów pomiarowych w danych eksploatacyjnych.

Zastosowano metodykę przedstawioną w artykułach $[13,14]$, polegającą na wykorzystaniu symulacyjnych modeli złożowych $[1,4,5,8,11]$ o parametrach geologicznych i charakterystykach udostępnień typowych dla dotychczas nawierconych i testowanych krajowych formacji łupkowych [9]. Ze względu na ograniczony zestaw takich danych oraz z powodu potrzeby analizowania dużego zbioru alternatywnych wariantów analizę przeprowadzono dla stosunkowo szerokiego zakresu słabo rozpoznanych parametrów formacji oraz dla ściślej zdefiniowanych parametrów, które zostały precyzyjniej określone.

W pracy wykorzystano specjalistyczne oprogramowanie do prowadzenia symulacji złożowych (Eclipse) firmy Schlumberger [10] oraz oprogramowanie własne do analizy uzyskanych wyników. 


\section{Metody krzywych spadku wydajności}

Metody krzywych spadku wydajności są od lat powszechnie stosowane w praktyce górnictwa naftowego w odniesieniu do złóż konwencjonalnych [3]. W ostatnim czasie używa się ich również w stosunku do złóż niekonwencjonalnych [7]. Zasadzają się one na heurystycznych prawach opisujących tempo zmian wydajności wydobycia $q$ (lub sumarycznego wydobycia $G_{p}$ ) ze złoża w funkcji czasu.

$\mathrm{W}$ niniejszym artykule przetestowano cztery typy modeli krzywych spadku wydajności. Są to:

- klasyczny model krzywej hiperbolicznej $[6] q(t)=\frac{q_{i}}{\left(1+n D_{i} t\right)^{1 / n}}$ scharakteryzowanej trzema parametrami: $q_{i}, n, D_{i}$ oraz modele stosowane dla złóż niekonwencjonalnych, $\mathrm{tj}$.:

- krzywa „wykładnicza rozciągnięta” (stretched exponential) [14]: $q=q_{i} \exp \left\{-\left(\frac{t}{\tau}\right)^{n}\right\}$, scharakteryzowana trzema parametrami: $q_{i}, n, \tau$,
- krzywa Duonga [2]: $q=q_{i} t^{-m} \exp \left\{b\left(t^{1-m}-1\right)\right\}$, scharakteryzowana trzema parametrami: $q_{i}, m, b$,

- krzywa logistyczna (logistc growth) [15]: $q=\frac{d G_{p}}{d t}$, $G_{p}=\frac{K t^{n}}{a+t^{n}}$, scharakteryzowana trzema parametrami: $K, n, a$

Identyfikacja parametrów powyższych krzywych uzyskana w procesie ich dopasowania do danych wydobywczych pozwala metodą regresji nieliniowej określić zasoby wydobywalne na poziomie poszczególnych odwiertów, jak i ich grup po skorzystaniu z relacji $G_{p}=\int{ }^{t f} q(t) d t$ i zastosowaniu warunków granicznych, np. maksymalnego czasu wydobycia $t_{f}$ lub minimalnej wydajności wydobycia $q_{\text {min }}$, odpowiadającej czasowi $t_{f} \mathrm{z}$ warunku $q\left(t_{f}\right)=q_{\text {min }}$. Do oceny statystycznych błędów szacowania zasobów wykorzystano metodę wielokrotnych realizacji modeli.

\section{Okresy dopasowania krzywych spadku wydajności wydobycia do danych eksploatacyjnych}

Ze względu na dwufazowy (gaz i woda) charakter przepływów złożowych w gazowych formacjach łupkowych, w danych eksploatacyjnych obserwuje się zjawisko osiągnięcia maksymalnej wydajności wypływu gazu z takiej formacji w charakterystycznym czasie $t_{\text {max }}$. Czas ten w zależności od parametrów złożowych i parametrów udostepnienia formacji może zmieniać się w dosyć szerokich granicach (od kilku do wielu dni). Ponieważ krzywe spadku wydajności można stosować tylko w fazie malejącej wydajności, okresy użyte do dopasowania tych krzywych muszą uwzględniać pracę złoża w fazie jednoznacznie spadkowej. W zastosowanej procedurze dopasowania definiowano początek i koniec okresu dopasowania względem czasu $t_{\max }$, np. pierwszy najwcześniejszy okres to przedział od $t_{\max }+1 / 2$ roku do $t_{\max }+1$ rok, następny to: $t_{\max }+1$ rok, $t_{\max }+2$ lata itd. Stosując ten schemat, przeprowadzono procedurę dopasowania do danych eksploatacyjnych dla czterech różnych okresów $\left(t^{\prime}=t-t_{\max }\right), 1 / 2$ roku $<t^{\prime}<1$ roku, 1 rok $<t^{\prime}$ $<2$ lata, 2 lata $<t^{\prime}<3$ lata, 3 lata $<t^{\prime}<4$ lata.

\section{Modele symulacyjne krajowych formacji łupkowych}

Skonstruowano wielowariantowe modele symulacyjne strefy drenażu pojedynczego odwiertu w formacji łupkowej o parametrach geologicznych i charakterystykach udostępnień typowych dla formacji krajowych. Modele te uwzględniały informacje uzyskane od operatorów złóż zaangażowanych w działalność nawiercania i testowania tych formacji. W efekcie modele te charakteryzowały się następującymi podstawowymi parametrami złożowymi i parametrami opisującymi udostępnienie formacji poziomymi odwiertami stymulowanymi wielosekcyjnym szczelinowaniem hydraulicznym:

- stałe parametry złożowe, tj. skład gazu: metan; temperatura złożowa $T=100^{\circ} \mathrm{C}$; początkowe ciśnienie złożowe $P_{i}=310 \mathrm{~b}$; miąższość $H=100 \mathrm{~m}$, porowatość matrycy $\phi_{m}=3,2 \%$; przepuszczalność matrycy $k_{m}=150 \mathrm{nD}$; pierwotne nasycenie wodą w matrycy $S_{w}=50 \%$; porowatość szczelin indukowanych $\phi_{f n}=0,1 \%$; porowatość hydroszczelin $\phi_{f h}=30 \%$,
- $\quad$ stałe parametry udostępnienia złoża: odwiert poziomy o długości odcinka poziomego $L_{h}=1000 \mathrm{~m}$; liczba sekcji hydroszczelinowania $n_{f}=10$; zasięg zabiegów hydroszczelinowania (połówkowa długość hydroszczelin) $l_{f}=150 \mathrm{~m}$; szerokość stref szczelin indukowanych $d_{f}=40 \mathrm{~m}$,

- pozostałe parametry złożowe (współczynnik sprzężenia matryca-szczeliny $\sigma$, przepuszczalność szczelin induko-

Tablica 1. Lista i zakresy zmienności parametrów złożowych

\begin{tabular}{|l|c|c|c|c|}
\hline \multicolumn{1}{|c|}{ Parametr } & \multicolumn{4}{c|}{ Wartości parametru } \\
\hline$\sigma\left[\mathrm{m}^{-2}\right]$ & 1 & 3 & 10 & - \\
\hline$k_{f n}[\mathrm{mD}]$ & 0,01 & 0,1 & 1 & - \\
\hline$k_{f h}[\mathrm{mD}]$ & 100 & 1000 & - & - \\
\hline$P_{L}[\mathrm{~b}]$ & 90 & 180 & 360 & - \\
\hline$D\left[\mathrm{~m}^{2} / \mathrm{d}\right]$ & 0 & 0,01 & 0,1 & 1 \\
\hline$V_{L}\left[\mathrm{~m}^{3} / \mathrm{kg}\right]$ & 0,01 & 0,1 & 0,4 & - \\
\hline
\end{tabular}


wanych (wtórnych), $k_{f n}$; przepuszczalność hydroszczelin $k_{f h}$; ciśnienie izotermy desorpcji Langmuira $P_{L}$; objętość izotermy desorpcji Langmuira $V_{L}$ ) przyjmowały zmienne wartości z zakresu podanego w tablicy 1.

Symulacje przeprowadzono dla ustalonych warunków eksploatacji określonych przez stałe ciśnienie na spodzie odwiertu wydobywczego $P_{b h p}=50$ bar.

\section{Procedura dopasowania krzywych spadku wydajności i określenia zasobów wydobywalnych}

Wyniki symulacji zbioru alternatywnych modeli formacji łupkowych wykorzystano jako dane eksploatacyjne w procedurze dopasowania krzywych spadku wydajności. Procedura ta (o charakterze regresji nieliniowej) pozwoliła wyznaczyć jednoznacznie komplet parametrów opisujących krzywe spadku wydajności. Efektywność użytej procedury była wysoka, a dokładność dopasowania bardzo duża dla wszystkich czterech zdefiniowanych wyżej modeli krzywych spadku i czterech okresów dopasowania. Przykład dopasowania krzywej spadku wydobycia do danych eksploatacyjnych przedstawiono na rysunku 1 - dla wydajności wydobycia, i na rysunku 2 - dla wydobycia sumarycznego.

Znajomość parametrów opisujących poszczególne krzywe spadku wydobycia pozwoliła na wyznaczenie sumarycznego wydobycia $G_{p}=\int{ }^{t f} q(t) d t$, traktowanego jako zasoby wydobywalne strefy drenażu pojedynczego odwiertu. Porównanie tej wielkości z analogicznymi wynikami symulacji modelu złożowego jest miarą błędu szacowania zasobów wydobywalnych metodą krzywych spadku wydajności.

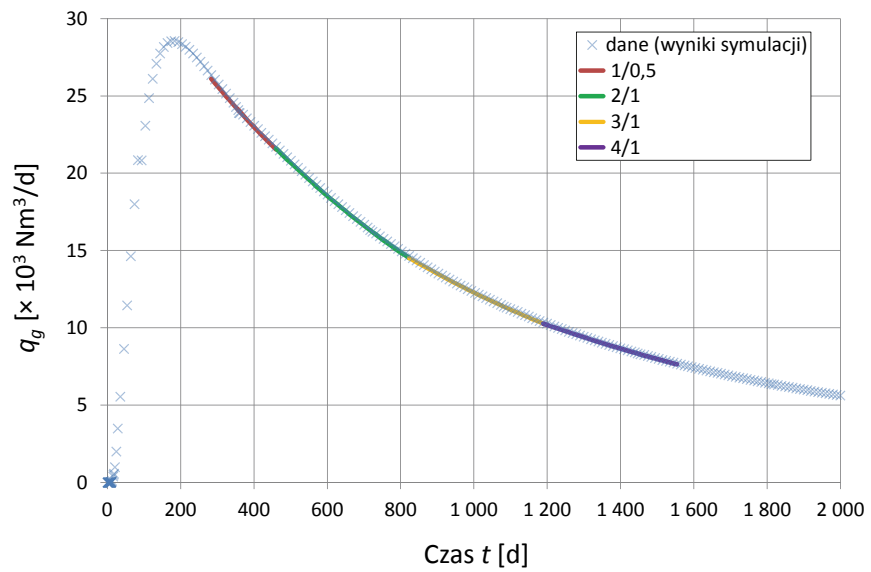

Rys. 1. Zależność wydajności wydobycia gazu $q_{g}$ od czasu $t$. Przykład dopasowania hiperbolicznego modelu krzywej spadku wydajności do danych (wyników symulacji) dla różnych okresów dopasowania
W efekcie powyższych założeń skonstruowano 648 wariantów symulacyjnych modeli krajowych formacji łupkowych, których wyniki symulacji w postaci wydajności i sumarycznego wydobycia gazu w funkcji czasu eksploatacji zostały wykorzystane do analizy efektywności metody krzywych spadku wydajności w procedurze wyznaczania wydobywalnych zasobów gazu z formacji łupkowych.

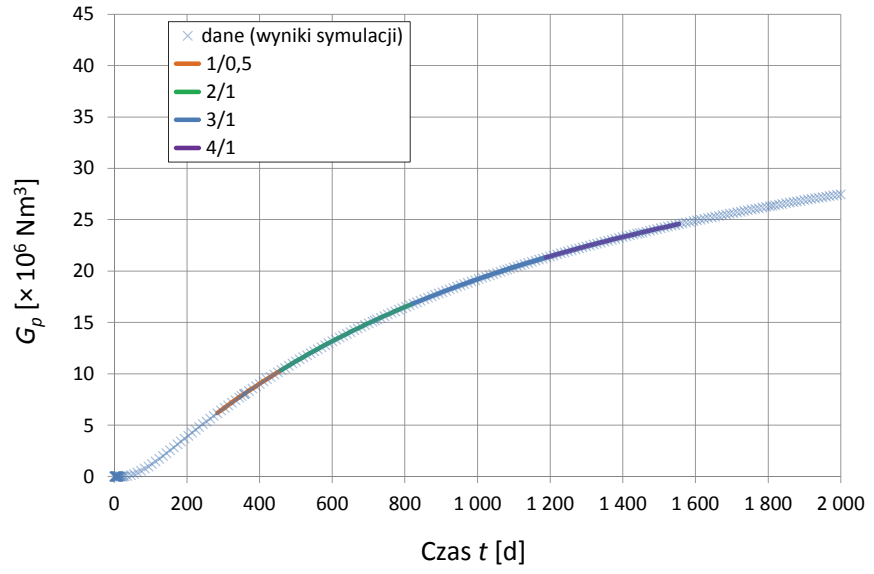

Rys. 2. Zależność sumarycznego wydobycia gazu $G_{p}$ od czasu $t$. Przykład dopasowania hiperbolicznego modelu krzywej spadku wydajności do danych (wyników symulacji) dla różnych okresów dopasowania

Przykład takiego porównania przedstawiono na rysunku 3 w postaci krzywych wydobycia sumarycznego (będących wynikiem symulacji) w odniesieniu do ekstrapolacji krzywych spadku wydajności.

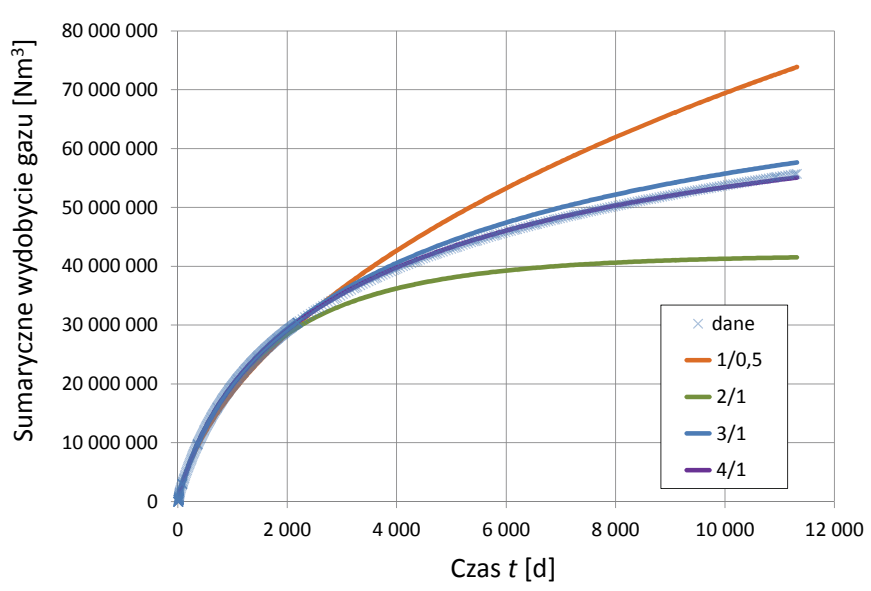

Rys. 3. Przykład ekstrapolacji krzywych spadku wydajności i ich porównania z wynikami symulacji

\section{Analiza porównawcza oceny zasobów wydobywalnych metodą krzywych spadku wydajności}

Powyższą procedurę dopasowania krzywych spadku wydajności i wyznaczania zasobów wydobywalnych zastosowano do wszystkich (648) wygenerowanych wcześniej wyników eksploatacyjnych alternatywnych modeli symulacyjnych 
krajowych formacji łupkowych. Dla każdej z powyżej zdefiniowanych krzywych uzyskano dopasowania w czterech różnych okresach, według powyżej opisanego schematu, symbolicznie oznaczonych jako: $1 / 0,5 ; 2 / 1 ; 3 / 1 ; 4 / 1$, odpowiadających całkowitemu czasowi symulacji/długości okresu dopasowania (w latach), licząc od momentu osiągnięcia maksymalnej wydajności gazu. Jakość dopasowania czterech krzywych we wszystkich okresach jest bardzo dobra, jednak wyniki ekstrapolacji tych krzywych w przypadku oszacowania zasobów wydobywalnych obarczone mogą być dużym błędem (rysunek 3). Zbiorcze wyniki w postaci średnich błędów (z 648 wariantów) oszacowania zasobów wydobywalnych przedstawiono w tablicy 2 i na rysunku 4, a odchylenie standardowe tych błędów w tablicy 3.

Spośród zastosowanych czterech modeli krzywych spadku wydajności model Duonga wykazuje najdokładniejsze średnie wyniki szacowania zasobów wydobywalnych, dla szerokiego zbioru alternatywnych modeli krajowych formacji łupkowych. Przewaga tego modelu nad pozostałymi objawia się dla co najmniej trzyletniego okresu dopasowania danych eksploatacyjnych i odpowiada błędowi szacowania zasobów wydobywalnych na poziomie 10\%. Dla krótszych okresów dopasowania wszystkie cztery użyte modele charakteryzują się średnim błędem odtworzenia zasobów przewyższającym $20 \%$ (dwuletni okres dopasowania) i 50\% (roczny okres dopasowania).

Szczegółowa analiza wyników ekstrapolacji w zależności od wartości poszczególnych parametrów pokazuje, że:

- wzrost parametru sprzężenia matryca-szczeliny zwiększa wielkość błędu szacowania zasobów,

- wzrost przepuszczalności szczelin wtórnych, jak i hydroszczelin, powoduje redukcję tego błędu,

- wzrost stałej dyfuzji wykazuje tendencję ograniczającą błędy szacowania zasobów,

- wzrost udziału gazu zaadsorbowanego w całkowitych zasobach gazu na ogół zwiększa błąd szacowania,

- wzrost ciśnienia Langmuira $P_{L}$ zmniejsza błąd szacowania. Powyższe wnioski mają zasadniczo wyjaśnienie w stopniu różniącym badany wariant od złoża konwencjonalnego, np. im większy parametr sprzężenia matryca-szczeliny, tym większy udział matrycy (o ekstremalnie niskich przepuszczal-

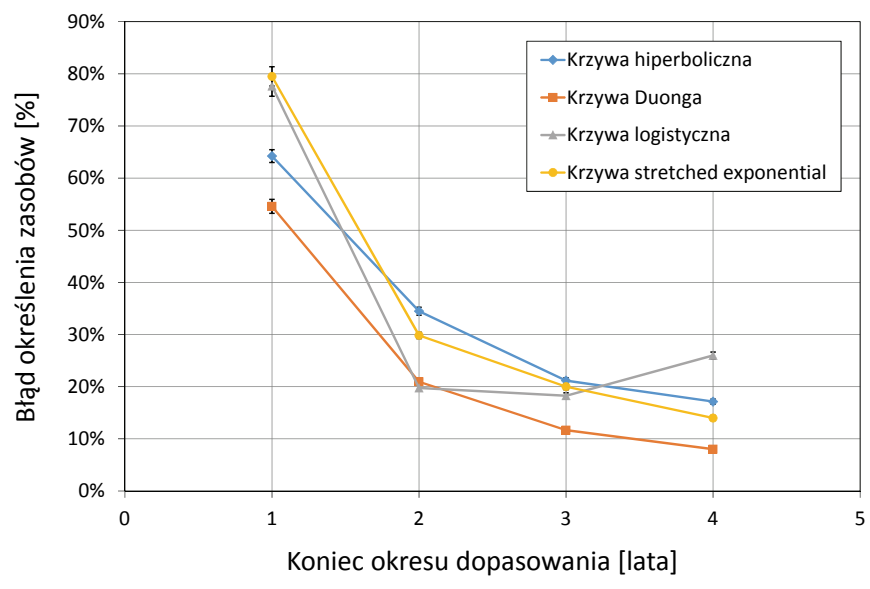

Rys. 4. Średnie błędy szacowania zasobów vs. okres dopasowania dla różnych krzywych spadku wydajności

Tablica. 2. Wartości średnie błędu szacowania zasobów wydobywalnych

\begin{tabular}{|c|c|c|c|c|}
\hline \multirow{2}{*}{$\begin{array}{c}\text { Okres } \\
\text { dopasowania }\end{array}$} & $\begin{array}{c}\text { Krzywa } \\
\text { hiperboliczna }\end{array}$ & $\begin{array}{c}\text { Krzywa } \\
\text { logistyczna }\end{array}$ & $\begin{array}{c}\text { Krzywa } \\
\text { Duonga }\end{array}$ & $\begin{array}{c}\text { Krzywa } \\
\text { streched } \\
\text { exponential }\end{array}$ \\
\cline { 2 - 5 } & \multicolumn{4}{|c|}{$[\%]$} \\
\hline $1 / 0,5$ & 64,23 & 77,65 & 54,58 & 79,50 \\
\hline $2 / 1$ & 34,47 & 19,75 & 20,93 & 29,84 \\
\hline $3 / 1$ & 21,17 & 18,25 & 11,65 & 20,00 \\
\hline $4 / 1$ & 17,14 & 25,99 & 8,01 & 13,99 \\
\hline
\end{tabular}

Tablica 3. Odchylenie standardowe błędu szacowania zasobów wydobywalnych

\begin{tabular}{|c|c|c|c|c|}
\hline \multirow{2}{*}{$\begin{array}{c}\text { Okres } \\
\text { dopasowania }\end{array}$} & $\begin{array}{c}\text { Krzywa } \\
\text { hiperboliczna }\end{array}$ & $\begin{array}{c}\text { Krzywa } \\
\text { logistyczna }\end{array}$ & $\begin{array}{c}\text { Krzywa } \\
\text { Duonga }\end{array}$ & $\begin{array}{c}\text { Krzywa } \\
\text { streched } \\
\text { exponential }\end{array}$ \\
\cline { 2 - 5 } & \multicolumn{5}{|c|}{$[\%]$} \\
\hline $1 / 0,5$ & 1,23 & 1,96 & 1,34 & 1,85 \\
\hline $2 / 1$ & 0,76 & 0,58 & 0,57 & 0,63 \\
\hline $3 / 1$ & 0,52 & 0,56 & 0,43 & 0,57 \\
\hline $4 / 1$ & 0,47 & 0,66 & 0,43 & 0,47 \\
\hline
\end{tabular}

nościach) w przepływach złożowych, które tym bardziej odbiegają od przepływów stacjonarnych lub semistacjonarnych i zachowują charakter przejściowy.

Podobnie zwiększony ułamek zasobów gazu w postaci gazu zaadsorbowanego oznacza bardziej złożony, w porównaniu z obiektami konwencjonalnymi, mechanizm przepływu w złożu.

Natomiast zwiększone ciśnienie Langmuira $P_{L}$, tak jak i wzrost stałej dyfuzji $D$, oznacza przyspieszoną desorpcję gazu i bardziej konwencjonalny charakter złoża. Analogiczny efekt obserwuje się dla przepuszczalności szczelin. 


\section{Wpływ błędów pomiarowych na niepewność szacowania zasobów wydobywalnych przy pomocy krzywych spadku wydobycia}

Powyżej analizowano niepewność szacowania zasobów wydobywalnych przy pomocy krzywych spadku wydobycia dopasowywanych do danych bez błędów. Poniższa analiza uwzględnia możliwość wystąpienia danych pomiarowych (wyników symulacji) z błędami.

W tym celu dane pomiarowe dla wydajności wydobycia zostały zaburzone błędem o rozkładzie normalnym z różnym odchyleniem standardowym, przyjmującym poziom: $1 \%, 3 \%$, 5\% i 10\% wartości pomiaru. Porównanie dopasowania krzywych wydajności wydobycia dla przypadków: bez tak określonych błędów pomiarowych i z błędem $10 \%$, przedstawiono odpowiednio na rysunkach 5 i 6 . Analogiczne porównanie dla wyników ekstrapolacji sumarycznego wydobycia zaprezentowano odpowiednio na rysunkach 7 i 8.

Analizę wpływu błędów pomiarowych na procedurę szacowania zasobów wydobywalnych przeprowadzono dla wybranych przypadków, badanych w poprzednich rozdziałach oraz 100 niezależnych realizacji błędów (tablica 4). Taka liczba

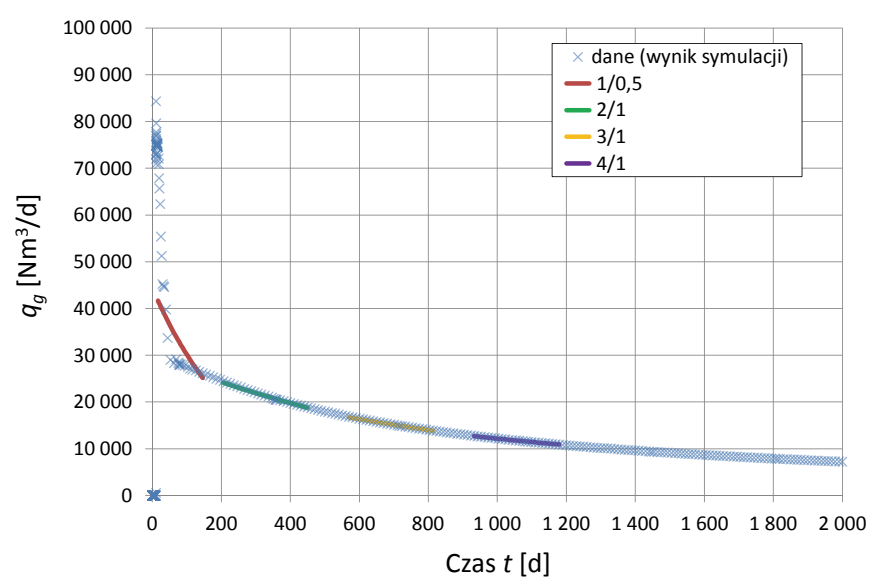

Rys. 5. Wyniki dopasowania hiperbolicznej krzywej spadku wydajności do „danych pomiarowych” (bez błędów)

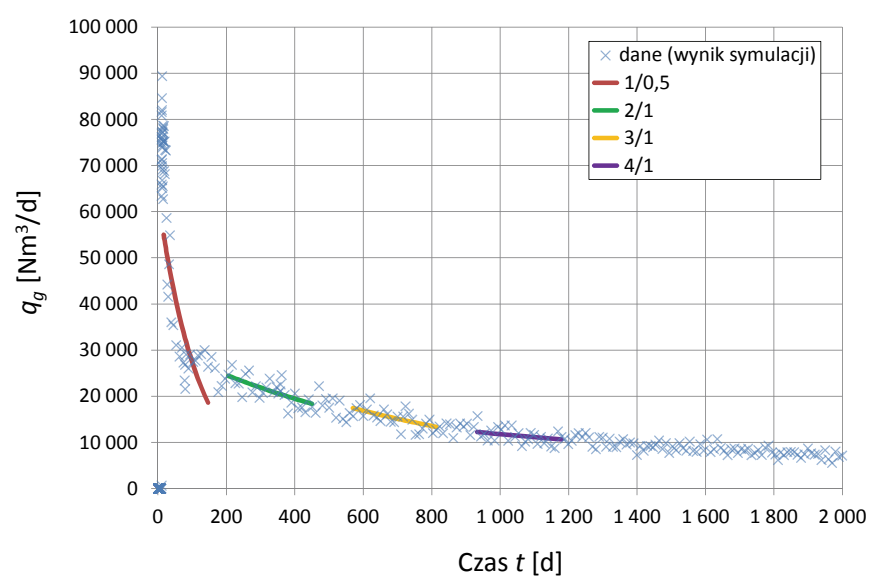

Rys. 6. Wyniki dopasowania hiperbolicznej krzywej spadku wydajności do „danych pomiarowych” (z błędem 10\%)

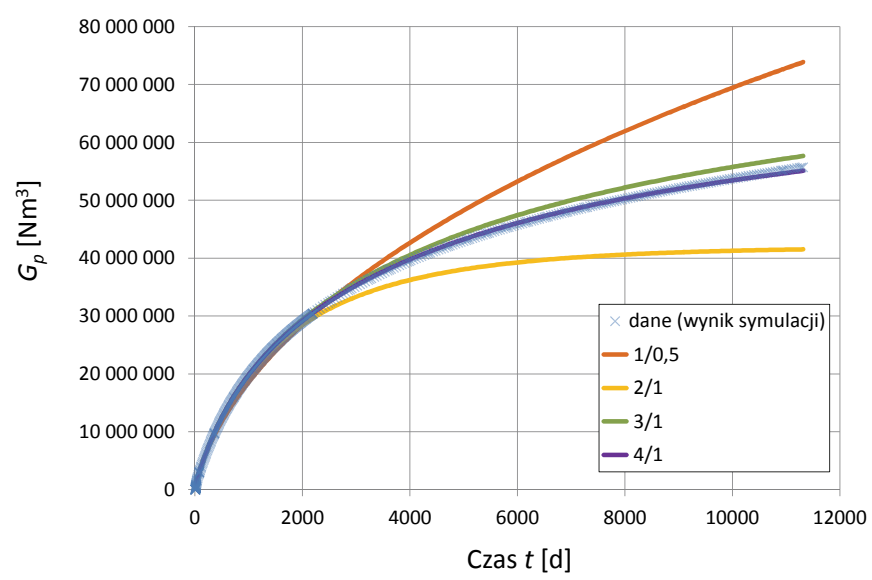

Rys. 7. Wyniki ekstrapolacji krzywej spadku typu stretched exponential dla szacowania zasobów wydobywalnych bez błędów

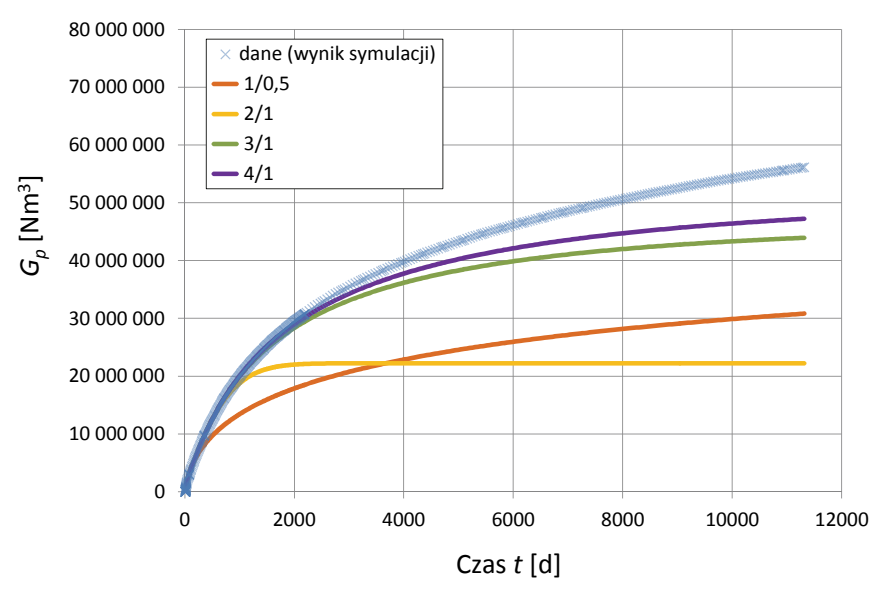

Rys. 8. Wyniki ekstrapolacji krzywej spadku typu stretched exponential dla szacowania zasobów wydobywalnych z błędem $10 \%$

realizacji zapewniała odchylenie standardowe znalezionych błędów szacowania zasobów poniżej 1\%. Rozpatrzono dwa skrajne przypadki (warianty modelu formacji), spośród analizowanych w poprzednich rozdziałach, charakteryzujące się bardzo dobrym i bardzo słabym odtworzeniem zasobów wydobywalnych omawianą metodą. Wynik takiej analizy wpływu błędów pomiarowych na procedurę szacowania zasobów wydobywalnych przedstawiono w tablicach 4 i 5 , odpowiednio dla dwu przykładowych wariantów o bardzo dokładnie i mało dokładnie odtworzonych zasobach, w warunkach z pominięciem błędu danych eksploatacyjnych.

Z zaprezentowanych danych wynika, że rozrzut pomiarów:

- zwiększa niepewność szacowania zasobów w przypadkach niewielkich rozbieżności procesu szacowania $(<10 \%)$,

- nie wpływa na niepewność szacowania zasobów przy dużych rozbieżnościach procesu szacowania (>20\%). 
Tablica. 4. Wpływ błędu danych eksploatacyjnych na dokładność szacowania zasobów wydobywalnych przykładowe wyniki dla przypadku dokładnie odtworzonych zasobów w warunkach z pominięciem błędu danych eksploatacyjnych - średnie ze 100 realizacji dla różnego rozmycia (błędu) danych eksploatacyjnych

\begin{tabular}{|c|c|c|c|c|}
\hline \multirow{2}{*}{$\begin{array}{c}\text { Błąd } \\
\text { pomiarów }\end{array}$} & \multicolumn{4}{|c|}{ Błąd szacowania zasobów } \\
\hline & $1 / 0,5$ & $2 / 1$ & $3 / 1$ & $4 / 1$ \\
\hline \multicolumn{5}{|c|}{$[\%]$} \\
\hline & \multicolumn{4}{|c|}{ krzywa hiperboliczna } \\
\hline 0 & 79,49 & 46,43 & 36,43 & 29,07 \\
\hline 1 & 87,16 & 47,05 & 37,00 & 29,35 \\
\hline 3 & 87,16 & 47,16 & 36,91 & 28,81 \\
\hline 5 & 87,15 & 46,54 & 36,43 & 29,10 \\
\hline \multirow[t]{2}{*}{10} & 87,16 & 45,49 & 35,00 & 28,22 \\
\hline & \multicolumn{4}{|c|}{ krzywa logistyczna } \\
\hline 0 & 91,58 & 14,42 & 6,35 & 4,46 \\
\hline 1 & 8,24 & 18,96 & 37,60 & 26,96 \\
\hline 3 & 8,08 & 19,70 & 37,68 & 26,93 \\
\hline 5 & 7,16 & 19,98 & 37,17 & 26,73 \\
\hline \multirow[t]{2}{*}{10} & 9,25 & 27,92 & 34,54 & 27,47 \\
\hline & \multicolumn{4}{|c|}{ krzywa stretched exponential } \\
\hline 0 & 32,57 & 25,49 & 3,46 & 1,13 \\
\hline 1 & 48,26 & 26,24 & 4,26 & 2,55 \\
\hline 3 & 48,56 & 35,98 & 6,17 & 5,35 \\
\hline 5 & 48,35 & 43,51 & 10,66 & 9,09 \\
\hline \multirow[t]{2}{*}{10} & 47,82 & 54,38 & 20,52 & 15,83 \\
\hline & \multicolumn{4}{|c|}{ krzywa Duonga } \\
\hline 0 & 68,26 & 13,27 & 9,62 & 4,17 \\
\hline 1 & 10,09 & 14,01 & 7,74 & 4,70 \\
\hline 3 & 9,16 & 13,52 & 7,23 & 6,34 \\
\hline 5 & 10,14 & 12,80 & 9,78 & 6,76 \\
\hline 10 & 9,95 & 14,33 & 13,18 & 15,65 \\
\hline
\end{tabular}

Tablica 5. Wpływ błędu danych eksploatacyjnych na dokładność szacowania zasobów wydobywalnych przykładowe wyniki dla przypadku mniej dokładnie odtworzonych zasobów w warunkach z pominięciem błędu danych eksploatacyjnych - średnie ze 100 realizacji dla różnego rozmycia (błędu) danych eksploatacyjnych

\begin{tabular}{|c|c|c|c|c|}
\hline \multirow{2}{*}{$\begin{array}{c}\text { Błąd } \\
\text { pomiarów }\end{array}$} & \multicolumn{4}{|c|}{ Błąd szacowania zasobów } \\
\hline & $1 / 0,5$ & $2 / 1$ & $3 / 1$ & $4 / 1$ \\
\hline \multicolumn{5}{|c|}{$[\%]$} \\
\hline & \multicolumn{4}{|c|}{ krzywa hiperboliczna } \\
\hline 0 & 69,14 & 32,76 & 26,52 & 22,07 \\
\hline 1 & 85,96 & 33,32 & 26,99 & 22,44 \\
\hline 3 & 85,96 & 32,19 & 26,34 & 22,59 \\
\hline 5 & 86,05 & 31,79 & 24,92 & 20,85 \\
\hline \multirow[t]{2}{*}{10} & 84,73 & 36,66 & 30,61 & 29,12 \\
\hline & \multicolumn{4}{|c|}{ krzywa logistyczna } \\
\hline 0 & 86,55 & 3,49 & 3,72 & 21,57 \\
\hline 1 & 66,78 & 27,68 & 46,90 & 33,46 \\
\hline 3 & 67,02 & 28,25 & 47,07 & 33,24 \\
\hline 5 & 67,10 & 27,22 & 46,59 & 33,52 \\
\hline \multirow[t]{2}{*}{10} & 66,49 & 31,15 & 44,59 & 31,65 \\
\hline & \multicolumn{4}{|c|}{ krzywa stretched exponential } \\
\hline 0 & 118,39 & 13,92 & 11,53 & 20,77 \\
\hline 1 & 48,44 & 84,92 & 38,58 & 21,28 \\
\hline 3 & 48,26 & 86,02 & 40,76 & 22,79 \\
\hline 5 & 50,25 & 85,70 & 37,33 & 24,98 \\
\hline \multirow[t]{2}{*}{10} & 47,71 & 88,47 & 46,59 & 28,25 \\
\hline & \multicolumn{4}{|c|}{ krzywa Duonga } \\
\hline 0 & 1,22 & 12,12 & 20,04 & 14,69 \\
\hline 1 & 52,59 & 15,60 & 17,41 & 14,82 \\
\hline 3 & 51,38 & 15,32 & 18,11 & 15,29 \\
\hline 5 & 50,27 & 16,42 & 20,81 & 17,37 \\
\hline 10 & 47,79 & 18,22 & 24,73 & 23,54 \\
\hline
\end{tabular}

\section{Wnioski}

Dokładność szacowania wydobywalnych zasobów formacji łupkowych przy pomocy analizy wydajności wydobycia metodą krzywych spadku jest efektem następujących czynników:

- poprawność zastosowanego modelu krzywej spadku,

- długość analizowanego okresu eksploatacji,

- wielkość rozmycia (błędy statystyczne) danych eksploatacyjnych.

Pierwszy z powyższych czynników ma charakter błędu systematycznego, a jego wpływ na dokładność szacowania zasobów może prowadzić zarówno do zawyżenia, jak i zani- żenia ich wartości. Analiza dużej liczby alternatywnych wariantów wskazuje na statystycznie najdokładniejsze szacowanie zasobów metodą krzywej Duonga w porównaniu z innymi modelami (krzywa hiperboliczna, typu stratched exponential, logistyczna) rozpatrywanymi w niniejszej pracy. Bardziej szczegółowa analiza wpływu wartości poszczególnych parametrów geologicznych formacji na dokładność szacowania zasobów opisywaną metodą pozwala sformułować ogólną zależność w postaci: błąd szacowania zasobów jest tym większy, im bardziej przepływy w eksploatowanej formacji odbiegają od przepływów stacjonarnych (semistacjonarnych). 
Drugi z powyższych czynników wyznacza naturalną korelację: im dłuższy okres analizy wydajności wydobycia (okres dopasowani krzywych spadku), tym dokładniejsze oszacowanie zasobów wydobywalnych. Względny błąd wyznaczenia zasobów na poziomie $10 \%$ wymaga co najmniej 3-letniego okresu analizy. Dla krótszego czasu błąd ten jest co najmniej rzędu 20\% - w przypadku okresu 2-letniego, i 50\% - rocznego.
Obecność statystycznych błędów pomiarowych w danych eksploatacyjnych (na poziomie do 10\% wartości pomiarów) zwiększa niepewność szacowania zasobów wydobywalnych w przypadkach, gdy dwa powyższe czynniki pozwalają na względnie dokładne wyznaczenie zasobów $(\leq 10 \%)$, oraz praktycznie nie wpływa na błąd ich szacowania przy dużych rozbieżnościach (>20\%) spowodowanych tymi czynnikami.

Prosimy cytować jako: Nafta-Gaz 2016, nr 9, s. 696-703, DOI: 10.18668/NG.2016.09.03

Artykuł nadesłano do Redakcji 4.04.2016 r. Zatwierdzono do druku 16.05.2016 r.

Artykuł powstał w ramach projektu pt. Dobór optymalnej metodyki szacowania zasobów oraz ryzyk poszukiwawczych (geologicznych i komercyjnych) złóż niekonwencjonalnych typu ,, shale gas”, , shale oil” oraz ,tight gas” w Polsce oraz opracowanie metodyki dokumentowania złóż niekonwencjonalnych. Zadanie WP1.7 Opracowanie metod i narzędzi probabilistycznej oceny zasobów gazu w złożach niekonwencjonalnych dla dynamicznych metod ich wyznaczania na zlecenie Narodowego Centrum Badań i Rozwoju; nr umowy: BG1/ŁUPZAS/13; nr archiwalny: DK-0601-8/13; nr zlecenia: 6111/KZ.

\section{Literatura}

[1] Anderson D. M., Nobakht M., Moghadam S., Mattar L.: Analysis of Production Data from Fractured Shale Gas Wells. SPE-131787-MS presented at the SPE Unconventional Gas Conference, Pittsburgh, Pennsylvania 23-25.02.2010. DOI http://dx.doi.org/10.2118/131787-MS.

[2] Anh N. Duong: Rate-Decline Analysis for Fracture-Dominated Shale Reservoirs. Society of Petroleum Engineers 2011, SPE137748-PA, vol. 14, nr 3, s. 377-387.

[3] Arps J. J.: Estimation of Decline Curves. Trans AIME 1945, 150 , s. 228-247.

[4] Cipolla C. L., Lolon E. P., Erdle J. C., Rubin B.: Reservoir Modeling in Shale-Gas Reservoirs. SPE-125530-PA. SPE Reservoir Evaluation \& Engineering 2010, vol. 13, Issue 04. DOI http://dx.doi.org/10.2118/125530-PA.

[5] Cipolla C. L., Lolon E., Mayerhofer M. J.: Reservoir Modeling and Production Evaluation in Shale-Gas Reservoirs. Paper IPTC-13185-MS presented at the International Petroleum Technology Conference, Doha, Qatar 7-9.12.2009. DOI http://dx.doi.org/10.2523/IPTC-13185-MS.

[6] Ilk D., Rushing J. A., Perego A. D., Blasingame T. A.: Exponential vs. Hyperbolic Decline in Tight Gas Sands: Understanding the Origin and Implications for Reserve Estimates Using Arps' Decline Curves. Paper SPE-116731-MS presented at the SPE Annual Technical Conference and Exhibition, Denver, Colorado 21-24.09.2008. DOI http://dx.doi. org/10.2118/116731-MS.

[7] Mattar L., Gault B., Morad K., Clarkson C. R., Freeman C. M. Ilk D., Blasingame T. A.: Production Analysis and Forecasting of Shale Gas Reservoirs: Case History-Based Approach. SPE-119897.
[8] Newsham K. E., Rushing J. A.: An Integrated Work-Flow Model to Characterize Unconventional Gas Resources: Part IGeological Assessment and Petrophysical Evaluation. Paper SPE 71351 presented at the SPE Annual Technical Conference and Exhibition, New Orleans, Louisiana, 30.09-3.10.2001. DOI: 10.2118/71351-MS.

[9] Opracowanie zbiorowe. Rzeczpospolita lupkowa. Studium wiedzy o gazie z formacji łupkowych. Prace Naukowe Instytutu Nafty i Gazu 2012, nr 183, s. 310.

[10] Pakiet Eclipse 100, 300 Release 2014.1 firmy GeoQuest, Schlumberger.

[11] Rushing J. A., Newsham K. E.: An Integrated Work-Flow Model to Characterize Unconventional Gas Resources: Part IIFormation Evaluation and Reservoir Modeling. Paper SPE 71352 presented at the SPE Annual Technical Conference and Exhibition, New Orleans, Louisiana, 30.09-3.10.2001. DOI: $10.2118 / 71352-M S$.

[12] Szott W., Gołąbek A.: Investigation of rate-decline analysis for assessment of recoverable reserves of polish shale gas formations. Nafta-Gaz 2015, nr 11, s. 864-869.

[13] Szott W., Gołąbek A.: Symulacje procesu eksploatacji złóż gazu ziemnego $w$ formacjach lupkowych (shale gas). Nafta-Gaz 2012, nr 12, s. 923-936.

[14] Valkó P. P., Lee W. J.: A Better Way To Forecast Production From Unconventional Gas Wells. Society of Petroleum Engineers 2010, SPE 134231-MS, Conference Paper.

[15] Verhulst P. F.: Notice sur la loi que la population poursuit dans son accroissement. Correspondance mathématique et physique 1838, 10, 131-121 Gand: Impr. d'H. Vandekerckhove.

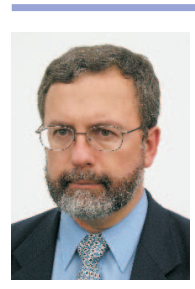

Dr Wiesław Szott

Adiunkt; kierownik Zakładu Symulacji Złóż

Węglowodorów i Podziemnych Magazynów Gazu.

Instytut Nafty i Gazu - Państwowy Instytut Badawczy

ul. Lubicz $25 \mathrm{~A}$

31-503 Kraków

E-mail: wieslaw.szott@inig.pl

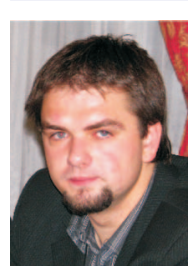

Mgr inż. Andrzej GOŁĄBEK

Asystent w Zakładzie Symulacji Złóż Węglowodorów i Podziemnych Magazynów Gazu.

Instytut Nafty i Gazu - Państwowy Instytut Badawczy

ul. Lubicz 25 A

31-503 Kraków

E-mail:andrzej.golabek@inig.pl 